This item was submitted to Loughborough's Research Repository by the author.

Items in Figshare are protected by copyright, with all rights reserved, unless otherwise indicated.

\title{
Prospects for treating foods with cold atmospheric gas plasmas
}

PLEASE CITE THE PUBLISHED VERSION

http://www.springerlink.com/content/978-94-007-2852-3\#section=1030473\&page=1\&locus=0

\section{PUBLISHER}

(C) Springer Science + Business Media B.V.

\section{VERSION}

AM (Accepted Manuscript)

\section{LICENCE}

CC BY-NC-ND 4.0

\section{REPOSITORY RECORD}

Shama, Gilbert, and Michael G. Kong. 2012. "Prospects for Treating Foods with Cold Atmospheric Gas Plasmas". figshare. https://hdl.handle.net/2134/9370. 
This item was submitted to Loughborough's Institutional Repository (https://dspace.lboro.ac.uk/) by the author and is made available under the following Creative Commons Licence conditions.

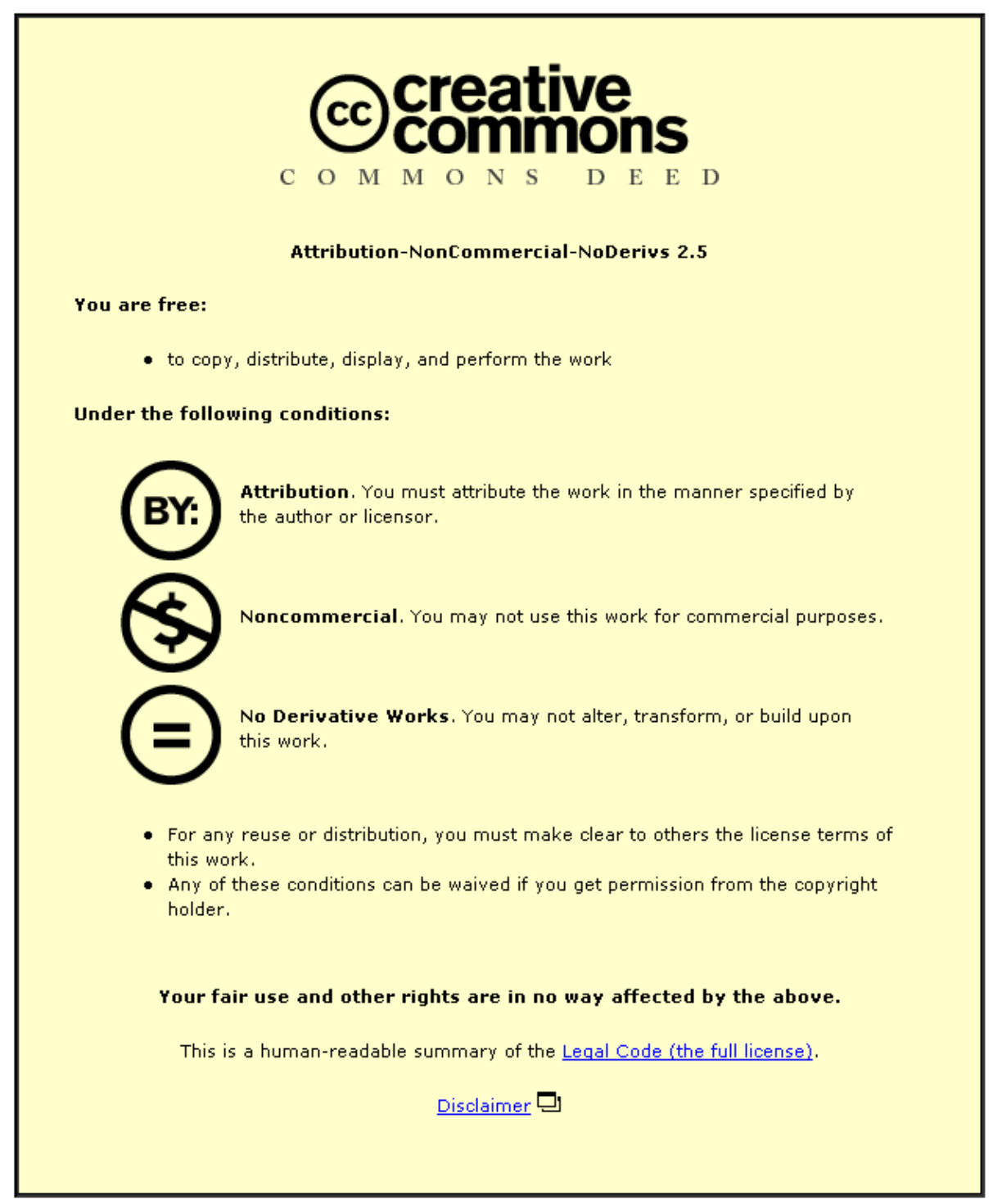

For the full text of this licence, please go to: http://creativecommons.org/licenses/by-nc-nd/2.5/ 


\title{
Prospects for Treating Foods with Cold Atmospheric Gas Plasmas
}

\author{
Gilbert Shama $^{1 *}$ and Michael G. Kong ${ }^{2}$ \\ ${ }^{1}$ Department of Chemical Engineering \\ ${ }^{2}$ Department of Electronic and Electrical Engineering \\ Loughborough University, Loughborough, LEICS., LE11 3TU, UK.
}

\begin{abstract}
In this review the potential applications of cold atmospheric gas plasmas are presented with particular reference to the problems of contamination of foods by biological agents. In addition to the accidental contamination of food, the very real threat arising from the deliberate contamination of the human food chain is also considered. The evidence that has been gained for the efficacy of cold plasmas in inactivating a wide range of biological agents is briefly surveyed. This is followed by an examination of previous work in which various types of foodstuffs have been successfully treated using cold gas plasmas. The need to demonstrate that the quality attributes of treated foods is not adversely affected is stressed. Finally, the role which gas plasmas may have in decontaminating food processing equipment is considered.
\end{abstract}

1. Introduction

The World Health Organisation (WHO) claims that 1.5 million children under five years of age die each year due to diarrhoea primarily as a result of contaminated drinking water and food. WHO also estimates that globally there are about 2 billion cases of diarrhoeal disease annually (WHO, 2009). This is not a phenomenon confined to the developing world; Mead et al. (1999) stated that in the United States there were 76 million incidences of foodborne disease resulting in 323, 000 hospitalizations and 5, 200 deaths annually. Moreover, this pattern is repeated in all industrialized countries. In England and Wales in the year 2000 for example, there were $1,338,772$ cases of foodborne infections resulting in 20, 759 hospitalizations and 480 deaths (Adak et al., 2002).

*Corresponding Author G.Shama@Lboro.ac.uk 
Increasingly more of the food we consume is subject to processing of one sort or another. Some form of processing must inevitably take place immediately following harvest or slaughter, but in industrialized countries food has become subject to ever more processing to meet the changing demands of consumers for convenience foods. There is mounting evidence to show that so-called ready to eat (RTE) foods such as fresh cut salads for example are increasingly becoming associated with incidences of foodborne disease (Sivapalasingam et al., 2004). This trend towards increased consumption of convenience foods is inevitably influencing the way in which the food industry produces such products. Production is increasingly becoming centralised into fewer, but larger, processing facilities. This in itself increases the impacts which isolated incidences of contamination of food products may have on the population as a whole. A telling example of this is an incident associated with the US dairy industry; a Salmonella outbreak in a single product - liquid ice cream - resulted in some 224, 000 people (Sobel et al., 2002) being affected. A more recent example concerns the Kellogg company. Salmonella-infected peanut butter obtained from one of the company's suppliers became incorporated into some of its snack products. In the ensuing epidemic of foodborne disease that followed 714 persons became infected in 43 states and there was evidence to suggest that infection from these food products may have been a contributory factor in 6 deaths. Moreover, the incident led to the recall of 7 million cases of Kelloggs' products (CDC, 2009).

Whilst there have been improvements in the microbiological safety of foods, few, if any foodborne pathogens have been contained over a sustained period of time. Bovine spongiform encephalitis (BSE) is still being detected in cattle, and the possibility cannot be entirely ruled out that BSE might have infected sheep fed the same 
contaminated feed supplements that caused the epidemic in cows (Fryer et al., 2007). Even apparent successes against particular agents hold little long term comfort; an increase in salmonellosis took place throughout the 1980s that was largely due to Salmonella Enteritidis Phage Type 4 which was found predominantly in poultry and eggs. Concerted action was taken in a number of countries which involved the wholesale slaughter of infected flocks coupled with extensive programmes of immunisations, and this proved successful as the incidences of this disease showed a significant decline during the 1990s. However, there are indications that since the year 2000 incidences are once more on the increase. The culprits are now different phage types of $S$. Enteritidis, and it appears that as one pathogen is effectively removed from a particular niche others evolve to take its place (Newell et al., 2010).

Another recent concern regarding food is the potential target it offers to terrorist organisations. Although Manning et al. (2005) cite a source claiming that since 1912 there have only been 12 documented cases of deliberate attempts to introduce pathogenic agents into foods or livestock, the current perceived threat level remains high. A further consequence of the centralisation of food processing is that it serves to increase the impact which terrorist attacks directed towards the food supply chain might have. Although there have been no concerted recent attempts made against national food supplies, examples exist that serve to expose both the vulnerability of the food supply chain and provide an indication of what the consequences of the deliberate contamination of elements of the supply chain could be. This is illustrated by an incident of contaminated Worcester sauce that occurred in the UK in 2006. One of the ingredients that was added to a batch of the sauce was chilli powder to which had been added a dye, Sudan Red I. The dye is not approved for food use and is in 
fact a Category 3 carcinogen. The sauce subsequently became widely distributed in a very large number of prepared foods and when the (deliberate) contamination of the chilli powder was discovered the UK Food Standards Agency ordered the withdrawal of over 600 different products from retail outlets (FSA, 2005). The motives in this case were financial rather than political or ideological but the extensive permeation of a single ingredient throughout a nation's food chain should serve as a salutary warning.

Another area of increasing concern in the food industry is the removal of traces of allergens from food processing facilities and equipment. If this could be achieved it would allow different products to be processed using the same equipment thus affording processors both versatility in the way they process foods and also cost savings. According to a review by Kagan (2003) between 1 and $2 \%$ of adults and between 5 and $7.5 \%$ of children in the United States are subject to food allergies of one sort or another. The food industry as a whole expends a great deal of effort in attempting to remove allergens from the surfaces of food processing equipment and has also to label its products using a rather convoluted system based on terms such as 'may contain', 'free from', 'suitable for' which are apt to confuse consumers and may ultimately lead a proportion of them to take risks (Ward et al., 2010). In essence this attests to the difficulty of assuring total removal of allergens.

In what follows below the emphasis will be on the potential that atmospheric, nonthermal gas plasmas have for the treatment of food in order to ensure its microbial safety. Reference to the challenges that have to be faced for this to be achieved will also be made as required. In addition to foods themselves, it is appropriate to consider 
the environments and the equipment used during the processing of food. The emphasis here will be on the opportunities for the application of plasma technology rather than on the technology itself. For the latter the excellent recent review by Ehlbeck et al. (2011) is strongly recommended.

2. The action of atmospheric gas plasmas against biological agents

There are about 200 known agents that are capable of causing disease when ingested (Acheson, 1999). These include chemical, physical and microbial agents. The latter comprise bacteria, fungi, parasites, viruses and prions and allergens. To date all of the biological agents that have been tested have proved themselves susceptible to the effects of plasma treatment. Naturally with reference to foods the aim must be to maximise the damage inflicted on the disease-causing agents whilst minimising any deleterious impacts on the food itself. The latter are quite complex assessments to make, but include damage to key nutrients, or changes in e.g. the texture or appearance of the food.

An understanding of the mechanisms by which gas plasmas bring about death or lethal injury to pathogenic agents could potentially lead to the enhancement of future treatment strategies through the manipulation of plasma conditions to maximise inactivation of pathogens. Perhaps the most-studied organisms to date have been the bacteria. Both Gram positive and Gram negative bacteria, biofilm-formers and bacterial spores have all been shown to be inactivated by gas plasmas (Deng et al., 2005; Vleugels et al., 2005; Opretzka et al., 2007; Perni et al., 2008a). It is also amongst this group of organisms that the greatest body of knowledge is being accumulated regarding mechanisms of inactivation. Moisan et al. (2002) attempted to 
infer information about possible mechanisms of inactivation of Bacillus subtilis spores by examining the form of survival curves and SEMs of spores post treatment. These workers concluded that UV photons played a significant role in the inactivation of the spores and were aided in this by oxygen atoms. Later, Perni et al. (2007) used E. coli mutants to show that the inactivation of these bacteria was primarily due to oxygen atoms and that the contributions of $\mathrm{UV}$ photons and $\mathrm{OH}^{\circ}$ radicals were relatively minor. Although these accounts might appear contradictory, the experimental data upon which they are based was conducted with different organisms, using different plasma systems and under different conditions. It will evidently be some time before the mechanism of inactivation of living cells can be unified. However, studies such as those cited above will hopefully continue to provide useful information and allow deeper insights into the principal mechanisms.

Moving away from bacteria, gas plasmas have also been used to inactivate fungal spores (Vohrer et al., 2001) and more recently, Avramidis et al. (2010) were able to show that plasmas caused deformation and disruption to the hyphae of growing fungi belonging to the genera Ascochyta and Fusarium. Previously Perni et al. (2008a) had demonstrated the plasma-induced inactivation of yeast of the species Saccharomyces cerevisiae.

Parasites have received rather less attention from the gas plasma community. Two important pathogens are Giardia lamblia and Cryptosporidium parvum (Smith, 1993). These organisms form oocysts - frequently simply referred to as 'cysts' - that are somewhat akin to bacterial and fungal spores in being able to withstand 
environmental hardships. Both are common waterborne organisms that resist chlorination - the currently employed methods for disinfecting water.

The number of foodborne incidents due to viruses is less well-documented owing to the difficulties in detecting viruses in foods. Notwithstanding, Roberts and Antonoplos (1998) were able to show that a hydrogen peroxide gas plasma sterilization unit was effective against a range of viruses including HIV type 1, hepatitis A virus, respiratory syncytial virus, vaccinia virus, herpes simplex virus type 1, and poliovirus type 2. Using a similar system, Vickery et al. (1999) obtained total inactivation of duck hepatitis virus as a model for human hepatitis B virus. Of the viruses selected in these studies, only hepatitis A is a foodborne virus, but the broad range of viral types inactivated by gas plasma suggests that other foodborne viruses such as Norovirus would also be susceptible to plasma treatment.

The term 'biological agent' not only includes living organisms but also their components and their products. One important category in this regard is the various types of proteins produced by living organisms. Deng et al. (2007) demonstrated the ability of gas plasmas to both destroy and physically remove a protein, bovine serum albumin (BSA), from the surface of stainless steel. This suggests a potential role for gas plasmas in inactivating prions which are the proteins responsible for bovine spongiform encephalopathy (BSE) and variant Creutzfeldt Jacob disease, (vCJB). More recently, Bayliss et al. (2009) used a pulsed radio frequency plasma jet to bring about the destruction and removal of amyloid fibrils from mica sheets. The former are viewed as a realistic non-infectious prion model. 
The results obtained using these model proteins also suggest that it may be possible to remove food allergens from the surfaces of food processing plant. The food processing industry has been obliged to take seriously the possibility of inducing allergenic reactions in the population at large and has adopted an approach based around that of Good Manufacturing Practices (GMP) that aim to assure segregation of allergenic ingredients and declaration of the possible existence of allergens as was mentioned above. Current decontamination practices centre on conventional cleaning techniques using detergents and sanitizers coupled with in some cases swab-based assays based on the detection of adenosine triphosphate (ATP) which can be used as a proxy indicator of the presence of protein on surfaces (Wang et al., 2010).

3. Atmospheric gas plasmas in the food industry

The most obvious application of gas plasmas in the food industry would be to employ them directly to decontaminate foods. Evidence has steadily been accumulating to show that gas plasmas can be used to effect reductions in microbial counts for a wide range of different foods covering virtually all food types including meat, dairy products and plant foods such as fruits, salad crops and nuts. A compilation of such results for a range of foods is shown in Table 1.

Whilst the number of foods that are being subjected to plasma treatment continues to increase and in many cases results in acceptable reductions in bacterial counts, a significant proportion of the studies listed in the table did not take into consideration whether treatment resulted in any deleterious effects in the food. This would include changes that might affect the quality, or the nutritional value, or even the appearance of the foodstuff itself. The exceptions to this statement are the investigations of 
Vleugels et al., (2005) with bell peppers, Basaran et al. (2008) on various types of nut, Niemira and Sites (2008) on apples, Ragni et al. (2010) on shell eggs, and Kim et al. (2011) for bacon. It cannot be stressed how important such considerations are as the chemical species produced in the plasmas possess the potential of bleaching the natural colour of foods and/or damaging key nutrients such as vitamins. Treatment could conceivably result in the peroxidation of lipids in fatty foods. Kim et al. (2011) attempted to conduct assays to establish whether plasma-treated bacon showed evidence of peroxidation but their results were inconclusive. In addition to what might be termed 'chemical effects', the gas flows used in the plasmas may result in moisture losses from the food undergoing treatment. These effects can all be quantified, but the ultimate test is consumer acceptance which needs to be assessed using specially trained panels.

Perhaps the next most important application of plasmas would be in the treatment of food processing equipment. Micro-organisms that attach to the surfaces of such equipment have been shown to cause the cross contamination of foods that subsequently come into direct contact with the contaminated surface (den Aantrekker et al., 2003). Arguably the most notorious case being that of the epidemic of typhoid caused in Aberdeen, Scotland in the summer of 1964. A catering sized can of corned beef from S. America contaminated with Salmonella was sliced using a food slicing machine in a grocer's premises in Aberdeen. The contaminated blade resulted in the cross contamination of other food products subsequently sliced using the machine and this resulted in an epidemic in which 500 people were hospitalised and a virtual national state of panic (Smith, 2007). This mechanism of microbial transfer has been investigated in studies conducted by Sheen and Hwang (2008) for ham slicing and by 
Perni et al. (2008b) for fresh fruit cutting. Leipold et al. (2010) proposed an innovative solution to this problem. They designed a dielectric barrier discharge (DBD) plasma system in which the circular cutting blade of a food slicing machine constituted one of the electrodes. With this they were able to demonstrate the efficient inactivation of Listeria innocua sprayed onto the blade. This represents a most interesting approach to the concept of decontaminating food processing machinery and points the way to extending the concept to other operations such as conveying etc. An unconventional approach to food preservation was taken by Fernandez-Gutierrez et al. (2010) who attempted to coat the surface of apples with vanillin using a plasmabased thin film deposition technique to protect the food against fungal spoilage. The conditions chosen by these researchers did not result in a continuous coating but rather in what they referred to as 'nodules'. The concept is however an interesting one and could be potentially applicable to other foods.

Another potential area where plasmas might make an impact is in food packaging. Although relatively little work appears to have been conducted using atmospheric gas plasmas, Heise et al. (2004) demonstrated the efficacy of DBD against bacterial and fungal spores deposited onto polymer foils.

The physical environment in which food processing takes place can occasionally become colonised by micro-organisms that appear to survive cycles of decontamination treatments and which are referred to as 'resident organisms' (Proudy et al., 2008). This may occur because some organisms are only exposed to sublethal concentrations of chemical disinfectants and thus are able to develop resistance against them (Walsh and Fanning, 2008). Although as stated above, the precise mode 
of action of gas plasmas has yet to be fully elucidated, it seems likely that more than one plasma species will be involved. This would lessen the possibility of organisms developing resistance.

The threats to the safety of foods resulting from potential terrorist action were briefly mentioned above. Certain sectors and elements of the food industry have been identified as being particularly vulnerable. Wein and Liu (2005) for example constructed a mathematical model to predict the consequences of the deliberate release of botulinum toxin into the milk supply chain in California, USA. The worst possible case envisaged the poisoning of up to some $5 \times 10^{5}$ people but this required a substantial quantity of toxin (of the order of $100 \mathrm{~g}$ ). Nevertheless, the implications are unsettling. A possibly more readily available toxin is ricin. Ricin is a potent toxin that is found in the castor oil plant. Its threat lies in part from the fact that the plant grows widely throughout the world and that it is relatively easy to extract from the castor bean 'mash' that remains after pressing for oil. Jackson et al. (2006) studied the thermal inactivation of ricin in reconstituted infant formula. They found that the some of the thermal treatment regimes currently in place were insufficient to inactivate the toxin. Existing measures to safeguard foods against microbial contamination may therefore not be sufficient to render harmless such toxins. Could plasmas be used to provide protection against such toxins? The literature would appear to indicate that the use of gas plasmas in this context has not been investigated, and therefore this warrants some attention by researchers in the field. A possible indication that they could is provided by the work of Birmingham and Hammerstrom (2000) who showed that plasmas possess the ability to destroy a mycotoxin in aerosolised form. However, 
considerably more work would be needed to extend their findings to the cases mentioned above.

\section{The future}

The range of foods subject to plasma treatment will doubtless continue to grow. If gas plasmas are ever to escape the confines of the laboratory and assume acceptance in the food industry a number of factors aside from their proven ability to inactivate pathogens, will need to be taken into account. This would include exhaustive testing to ensure that foods that have been treated with plasmas do not undergo any undesirable changes that would render them harmful, unpalatable or otherwise unsaleable. Absolute proof that no harmful products have been produced is actually very difficult, if not impossible, to demonstrate as the list of potential toxic byproducts is a very long one. Ensuring the quality of treated foods is a rather more straightforward undertaking. This would include tests for key nutrients such as vitamins, textural studies, colour etc. The issue of public perception of foods treated with gas plasmas is also one that needs addressing. Ill-informed publicity could impact negatively on the chances of this technology being adopted by the food industry.

Mention was made above of the increasing popularity of RTE foods and the problems associated with minimally processed foods such as salads etc. One assessment of the current state of affairs is that the available technology for disinfection has not kept pace with the changing eating habits of consumers and that an effective and adaptable new decontamination technology is sorely needed. Adaptability will be essential, as 
not only must the technology prove itself efficacious against current pathogens, but it will need to provide assurance that it can operate equally effectively against emerging pathogens. Climate change will constitute one driver of change. That it will influence global food production can surely not be in doubt (Schmidhuber and Tubiello, 2007), more uncertain however will be its impact on food pathogens. Increases in temperature will have some direct effects including increasing the growth rate of most of the common foodborne pathogens. But it will also influence eating behaviour. Warmer temperature are associated with increased consumption of salads and barbecued foods- both of which have been heavily implicated in incidences of foodborne disease (Lake et al., 2009).

One assessment of the true scale of the problem faced by any decontamination technology may be gained from a telling statement from the work of Newell et al. (2010); 'over millennia all food-borne pathogens have developed efficient and effective strategies, which exploit, wholly or in part, food as a vehicle to transfer from one human gut host to another, or from an animal to a human. The mechanisms involved are complex and varied but all are able to survive intervening periods in the environment, and then avoid the human innate gut defences to colonize and multiply rapidly before enabling effective dispersal, frequently through fluid faeces, back into the environment to progress again through each cycle.' 


\begin{tabular}{|c|c|c|c|}
\hline Foodstuff & $\begin{array}{l}\text { Targeted Micro- } \\
\text { organisms }\end{array}$ & Treatment Details & Reference \\
\hline Almonds & E. coli & $\begin{array}{l}5 \log \text { reductions after } 30 \\
\text { s. }\end{array}$ & $\begin{array}{l}\text { Deng et al. } \\
\text { (2007) }\end{array}$ \\
\hline Apples & $\begin{array}{l}\text { E. coli } \mathrm{O} 157: \mathrm{H} 7 \\
\text { Salmonella } \text { Stanley }\end{array}$ & $\begin{array}{l}\text { Salmonella; } 2.9 \text { to } 3.7 \\
\log \text { reductions after } 3 \\
\text { min. } \\
\text { E. coli } \mathrm{O} 157: \mathrm{H} 7 \\
2.6 \text { to } 3 \text { log reductions } \\
\text { after } 3 \text { min. }\end{array}$ & $\begin{array}{l}\text { Niemira and } \\
\text { Sites (2008) }\end{array}$ \\
\hline Apples & E. coli $\mathrm{O} 157: \mathrm{H} 7$ & $\begin{array}{l}>2 \log \text { reductions after } 2 \\
\text { min. }\end{array}$ & $\begin{array}{l}\text { Critzer et al. } \\
(2007)\end{array}$ \\
\hline Bacon & $\begin{array}{l}\text { Listeria } \\
\text { monocytogenes } \\
\text { Salmonella } \\
\text { Typhimurium } \\
\text { E. coli }\end{array}$ & $\begin{array}{l}4.6 \text { log reductions after } \\
1.5 \mathrm{~min} . \\
\text { (results reported as 'total } \\
\text { aerobic counts') }\end{array}$ & $\begin{array}{l}\text { Kim et al. } \\
(2011)\end{array}$ \\
\hline Cheese & $\begin{array}{l}\text { Listeria } \\
\text { monocytogenes }\end{array}$ & $\begin{array}{l}>8 \text { log reductions in } 2 \\
\text { min. }\end{array}$ & $\begin{array}{l}\text { Song et al. } \\
(2009)\end{array}$ \\
\hline Eggs & $\begin{array}{l}\text { Salmonella } \\
\text { Enteritidis } \\
\text { Salmonella } \\
\text { Typhimurium }\end{array}$ & $\begin{array}{l}S . \text { Enteritidis } 4.5 \log \\
\text { reductions after } 90 \mathrm{~min} \text {. } \\
S \text {. Typhimurium } \sim 3.7 \mathrm{log} \\
\text { reductions after } 90 \mathrm{mins}\end{array}$ & $\begin{array}{l}\text { Ragni et al. } \\
(2010)\end{array}$ \\
\hline Ham & $\begin{array}{l}\text { Listeria } \\
\text { monocytogenes }\end{array}$ & $\begin{array}{l}1.7 \text { log reductions after } 2 \\
\text { min. }\end{array}$ & $\begin{array}{l}\text { Song et al. } \\
(2009)\end{array}$ \\
\hline Lettuce & $\begin{array}{l}\text { Listeria } \\
\text { monocytogenes }\end{array}$ & $\begin{array}{l}1 \log \text { reduction after } 1 \\
\text { min. }\end{array}$ & $\begin{array}{l}\text { Critzer et al. } \\
(2007)\end{array}$ \\
\hline Mango & $\begin{array}{l}\text { E. coli } \\
\text { Saccharomyces } \\
\text { cerevisiae } \\
\text { Pantoea agglomerans } \\
\text { Gluconobacter } \\
\text { liquefaciens }\end{array}$ & $\begin{array}{l}P . \text { agglomerans \& } G . \\
\text { liquefaciens }>3 \log \\
\text { reductions after } 2.5 \mathrm{~s} . \\
\text { E. coli }>3 \log \text { reductions } \\
\text { after } 5 \mathrm{~s} . \\
\text { S. cerevisiae }>3 \log \\
\text { reductions after } 30 \mathrm{~s} .\end{array}$ & $\begin{array}{l}\text { Perni et al. } \\
(2008 \mathrm{a})\end{array}$ \\
\hline $\begin{array}{l}\text { Melon } \\
\text { (Cantaloupe) }\end{array}$ & $\begin{array}{l}\text { Salmonella } \\
\text { (Unspecified } \\
\text { serovars) }\end{array}$ & $\begin{array}{l}>2 \log \text { reductions after } 1 \\
\text { min. }\end{array}$ & $\begin{array}{l}\text { Critzer et al. } \\
(2007)\end{array}$ \\
\hline $\begin{array}{l}\text { Melon } \\
\text { (Honeydew) }\end{array}$ & $\begin{array}{l}\text { E. coli } \\
\text { Saccharomyces } \\
\text { cerevisiae } \\
\text { Pantoea agglomerans } \\
\text { Gluconobacter } \\
\text { liquefaciens }\end{array}$ & $\begin{array}{l}P . \text { agglomerans } \& G . \\
\text { liquefaciens }>3 \log \\
\text { reductions after } 2.5 \mathrm{~s} \text {. } \\
\text { E. coli }>3 \log \text { reductions } \\
\text { after } 5 \mathrm{~s} . \\
\text { S. cerevisiae }>3 \log \\
\text { reductions after } 10 \mathrm{~s} .\end{array}$ & $\begin{array}{l}\text { Perni et al. } \\
\text { (2008a) }\end{array}$ \\
\hline Pork & E. coli & $\begin{array}{l}6 \log \text { reductions after } 0.5 \\
\text { min. }\end{array}$ & $\begin{array}{l}\text { Moon et al. } \\
(2009)\end{array}$ \\
\hline $\begin{array}{l}\text { Nuts; } \\
\text { Hazelnuts, } \\
\text { Peanuts \& } \\
\text { Pistachios }\end{array}$ & $\begin{array}{l}\text { Aspergillus } \\
\text { parasiticus }\end{array}$ & $\begin{array}{l}1 \log \text { reduction after } 5 \\
\text { min. } \\
5 \log \text { reductions in the } \\
\text { presence of } \mathrm{SF}_{6}\end{array}$ & $\begin{array}{l}\text { Basaran et al. } \\
(2008)\end{array}$ \\
\hline
\end{tabular}

Table 1. Foods treated with atmospheric gas plasmas. 
References

Acheson, D. W. K. 1999. Foodborne infections. Current Opinion in Gastroenterology. 15, 538-545.

Adak, G. K., Long, S. M., and O'Brien, S. J. 2002. Trends in indigenous foodborne diseases and deaths, England and Wales:1992 to 2000. Gut. 51, 832-841.

Avramidis, G., Stüwe, B., Wascher, R., Bellmann, M., Wieneke, S., von Tiedemann, A., and Viöl, W. 2010. Fungicidal effects of an atmospheric pressure gas discharge and degradation mechanisms. Surface and Coatings Technology. 205, S405 -S408.

Basaran, P., Basaran-Akgul, N., Oksuz, L. 2008. Elimination of Aspergillus parasiticus from nut surface with low pressure cold plasma (LPCP) treatment. Food Microbiology. 25, 626-632.

Bayliss, D. L., Walsh, J. L., Shama, G., Iza, F., Kong, M.G. 2009. Reduction and degradation of amyloid aggregates by a pulsed radio-frequency cold atmospheric plasma jet. New Journal of Physics. 11, Article Number: 115024.

Birmingham, J.G., and Hammerstrom, D. J. 2000. Bacterial Decontamination Using Ambient Pressure Nonthermal Discharges. IEEE Transactions on Plasma Science. 28, 51-55.

CDC (Centers for Disease Control), 2009. Investigation update: outbreak of Salmonella Typhimurium infections, 2008-2009.

http://www.cdc.gov/salmonella/typhimurium/update.html.

Critzer, F. J., Kelly-Wintenberg, K., South, S. L., and Golden, D. A. (2007).

Atmospheric plasma inactivation of foodborne pathogens on fresh produce surfaces. Journal of Food Protection. 70, 2290-2296.

den Aantrekker E. D., Boom R. M., Zwietering M. H., and van Schthorst M. 2003. Quantifying recontamination through factory environments - a review. Int. J. Food Microbiol. 80, 117- 130.

Deng, S., Ruan, R., Mok, C. K., Huang, G., Lin, X., and Chen, P. 2007. Inactivation of Escherichia coli on almonds using nonthermal plasma. Journal of Food Science. 72, M62-M66.

Deng, X. T., Shi, J. J., Shama G., and Kong, M.G. 2005.

Effects of microbial loading and sporulation temperature on atmospheric plasma inactivation of Bacillus subtilis spores. Applied Physics Letters. 87, Article Number: 153901. 
Deng, X. T., Shi, J. J., and Kong, M. G. 2007. Protein destruction by a helium atmospheric pressure glow discharge: Capability and mechanisms. Journal of Applied Physics. 101, Article Number: 074701.

Ehlbeck, J., Schnabel, U., Polak, M., Winter, J., von Woedtke, T., Brandenburg, R., von dem Hagen, T., and Weltmann, K-D. 2011. Low temperature atmospheric pressure plasma sources for microbial decontamination. Journal of Physics D: Applied Physics. 44, Article No. 013002.

Fernandez-Gutierrez, S. A., Pedrow, P. P. Pitts, M. J., and Powers, J. 2010. Cold atmospheric pressure plasmas applied to active packaging of apples. IEEE Transactions on Plasma science. 38, 957-965.

Fryer, H. R., Baylis, M., Sivam, K., McLean, A. R. 2007. Quantifying the risk from ovine BSE and the impact of control strategies. Proceedings of the Royal Society B. 274, 1497-1503.

FSA (Food Standards Agency, UK), 2005. Sudan 1 consolidated product list from February 2005 recall.

http://www.food.gov.uk/safereating/chemsafe/sudani/sudanlistno. Accessed January $27^{\text {th }}$.

Heise, M., Neff, W., Franken, O., Muranyi, P., and Wunderlich, J. 2004. Sterilization of polymer foils with dielectric barrier discharges at atmospheric pressure. Plasmas and Polymers. 9, 23-33.

Jackson, L. S., Tolleson, W. H., and Chirtel, S. J. 2006. Thermal inactivation of ricin using infant formula as a food matrix. Journal of Agricultural and Food Chemistry. 54, 7300-7304.

Kagan, R. S. 2003. Food allergy: An overview. Environmental Health Perspectives, 111, 223-5.

Kim, B., Yun, H., Jung S., Jung, Y., Jung, H., Choe, W., and Jo, C. 2011. Effect of atmospheric pressure plasma on inactivation of pathogens inoculated onto bacon using two different gas compositions. Food Microbiology. 28, 9-13.

Lake, I. R., Gillespie, I. A., Bentham, G., Nichols, G. L., Lane, C., Adak, G. K., Threlfall, E. J. 2009. A re-evaluation of the impact of temperature and climate change on

foodborne illness. Epidemiology and Infection. 137, 1538-1547.

Leipold, F., Kusano, Y., Hansen, F., and Jacobsen, T. (2010). Decontamination of a rotating cutting tool during operation by means of atmospheric pressure plasmas. Food Control. 21, 1194-1198. 
Manning, L., Baines, R.N., and Chadd, S.A. 2005. Deliberate contamination of the food supply chain. British Food Journal. 107, 225-245.

Mead, P. S. , Slutsker, L., Dietz, V., McCraig, L. F., Bresee, J. S., Shapiro, C., Griffin, P.M., and Tauxe, R.V. 1999. Food-related illness and death in the United States.

Emerging Infectious Diseases. 5, 607-625.

Moisan, M., Barbeau, J., Crevier, M-C., Pelletier, J., Philip, N., and Saoudi, B. 2002. Plasma sterilization. Methods and mechanisms. Pure and Applied Chemistry. 74, 349358.

Moon, S. Y., Kim, D. B., Gweon, B., Choe, W., Song, H. P., and Jo, C. 2009.

Feasibility study of the sterilization of pork and human skin surfaces by atmospheric pressure plasmas. Thin Solid Films. 517, 4272-4275.

Newell, D. G., Koopmans, M., Verhoef, L., Duizer, E., Aidara-Kane, A., Spromng, H., Opsteegh, M., Langelaar, M., Threfall, J., Scheutz, F., van der Giessen, J., and Kruse, H. 2010. Food-borne diseases - The challenges of 20 years ago still persist while new ones continue to emerge. International Journal of Food Microbiology. 139, S13- S15.

Niemira, B. A., and Sites, J. 2008. Cold plasma inactivates Salmonella Stanley and Escherichia coli O157:H7 inoculated on Golden Delicious apples. 2008. Journal of Food Protection. 71, 1357-1365.

Opretzka, J., Benedikt, J., Awakowicz, P., Wunderlich, J., and von Keudell, A. 2007. The role of chemical sputtering during plasma sterilization of Bacillus atrophaeus. Journal of Physics D, Applied Physics. 40, 2826-2830.

Perni, S., Shama, G., Hobman, J. L., Lund, P. A., Kershaw, C. J., Hidalgo-Arroyo, G. A., Penn, C. W., Deng, X. T., Walsh, J. L., Kong, M. G. 2007. Probing bactericidal mechanisms induced by cold atmospheric plasmas with Escherichia coli mutants. Applied Physics Letters. 90, Article No., 073902.

Perni, S., Liu, D. W., Shama, G., and Kong, M. G. 2008a. Cold Atmospheric Plasma Decontamination of the pericarps of fruit. Journal of Food Protection. 71, 302-308.

Perni, S., Shama, G., and Kong, M.G. 2008b. Cold atmospheric plasma disinfection of cut fruit surfaces contaminated with migrating microorganisms. Journal of Food Protection. 71, 1619-1625.

Proudy, I., Bougle, D., Leclercq, R., and Vergnaud, M. Tracing of Enterobacter sakazakii isolates in infant milkformula processing by BOX-PCR genotyping. 2008. Journal of Applied Microbiology. 105, 550-558.

Ragni, L ., Berardinelli, A., Vannini, L (Vannini, Lucia); Montanari, C., Sirri, F., Guerzoni, M. E., Guarnieri, A. 2010.

Non-thermal atmospheric gas plasma device for surface decontamination of shell eggs Journal of Food Engineering. 100, 125-132. 
Roberts, C., and Antonoplos, P. 1998. Inactivation of human immunodeficiency virus type 1 , hepatitis A virus, respiratory syncytial virus, vaccinia virus, herpes simplex virus type 1 , and poliovirus type 2 by hydrogen peroxide gas plasma sterilization. American Journal of Infection Control. 26, 94-101.

Schmidhuber, J., and Tubiello, F. N. 2007. Global food security under climate change. Proceedings of the National Academy of Sciences. 104, 19703-19708.

Sheen, S., and Hwang, C. 2008. Modeling Transfer of Listeria monocytogenes from Slicer to Deli Meat During Mechanical Slicing. Foodborne Pathogens and Disease. 5, 135-146.

Sivapalasingam, S., Friedman, C. R., Cohen, L., and Tauxe, R. V. 2004. Fresh produce: a growing cause of outbreaks of foodborne illness in the United States, 1973 through 1997. Journal of Food Protection. 67, 2342-53.

Smith, D. F. 2007. Food panics in history: corned beef, typhoid and "risk society" Journal of Epidemiology and Community Health. 61, 566-570.

Smith, J. L., 1993.Cryptosporidium and Giardia as Agents of Foodborne Disease. Journal of Food Protection, 56, 451-461.

Sobel, J., Khan, A. S., and Swerdlow, D. L., 2002. Threat of a biological terrorist attack on the US food supply: the CDC perspective. The Lancet. 359, 874-880.

Song, H. P., Kim, B., Choe, J. H., Jung, S., Moon, S. Y., Choe, W., and Jo, C. 2009. Evaluation of atmospheric pressure plasma to improve the safety of sliced cheese and ham inoculated by 3-strain cocktail Listeria monocytogenes. Food Microbiology. 26, 432-436.

Vickery, K., Deva, A. K., Zou, J., Kumaradeva, P., Bissett, L., and Cossart, Y. E. 1999. Inactivation of duck hepatitis B virus by a hydrogen peroxide gas plasma sterilization system: laboratory and 'in use' testing. Journal of Hospital Infection. 41, $317-322$.

Vleugels, M., Shama, G., Deng, X. T., Greenacre, E., Brocklehurst, T., and Kong, M. G. 2005. Atmospheric plasma inactivation of biofilm-forming bacteria for food safety control. IEEE Transactions on Plasma Science. 33, 824-828.

Vohrer, U., Trick, I., Bernhardt, J., Oehr, C., and Brunner, H. 2001. Plasma treatment - an increasing technology for paper restoration? Surface and Coatings Technology. 142, 1069-1073.

Walsh, C., and Fanning, S. 2008. Antimicrobial Resistance in Foodborne Pathogens A Cause for Concern? Current Drug Targets. 9, 808-815.

Wang, X., Young, O. A., and Karl, D. P. 2010. Evaluation of cleaning procedures for allergen control in a food industry environment. Journal of Food Science, 75, T149$\mathrm{T} 155$. 
Ward, R., Crevel, R., Bell, I., Khandke, N., Ramsay, C., and Paine, S. 2010. A vision for allergen management best practice in the food industry. Trends in Food Science and Technology. 21, 619-625.

Wein, L. M. And Liu, Y. 2005. Analyzing a bioterror attack on the food supply: The case of botulinum toxin in milk. PNAS. 102, 9984-9989.

WHO (World Health Organisation), 2009. Diarrhoel Disease.

http://www.who.int/mediacentre/factsheets/fs330/en/index.html. Accessed January 27 th. 